\title{
Diaspore Abundance Promotes more Interaction with Ants in a Brazilian Atlantic Forest
}

\author{
Bianca Ferreira Silva ${ }^{1}$ (1) 0000-0002-2400-7261 \\ Igor Henrique Freitas Azevedo ${ }^{2}$ (1) 0000-0002-0861-4678 \\ Antonio Mayhé-Nunes ${ }^{1}$ (1) 0000-0002-1111-9256 \\ André Felippe Nunes-Freitas ${ }^{1}$ (D) 0000-0002-5149-9070
}

\begin{abstract}
The influence of Guarea guidonia (L.) Sleumer diaspore abundance on ants' preference was studied in a secondary tropical forest area in Brazil. We offered seeds in stations with different abundances (one, two, five or 10 diaspores) for interactions with ants. The number of interactions and of ants were influenced by diaspore abundance during the observation period. Stations with 10 diaspores maintained a high number of interactions throughout the experiment. Incidence of seed cleaning differed among the four groups. Moreover, the number of interactions was positively related to the average percent of seeds cleaned. Diaspore abundance proved to be important for promoting more interactions with ants. Considering that the proportion of seeds cleaned increased with the number of interactions, further experiments should observe ant activity for a longer period. Furthermore, diaspore abundance should be considered in future studies of interactions with ants.
\end{abstract}

Keywords: ant-fruit interaction, seed abundance, foraging behavior, Guarea guidonia, Meliaceae.

\section{INTRODUCTION AND OBJECTIVES}

Myrmecochory (i.e., seed dispersal by ants) occurs worldwide, mainly in the temperate forests of North America and the arid environments of South Africa and Australia (Lengyel et al., 2010). These plants have diaspore (i.e., the dispersal unit of the plant, usually a seed) with elaiosomes, a lipid-rich appendage. In tropical forests, interactions with ants frequently occur in non-myrmecochorous plants. They lack elaiosomes, but have other seed structures attractive to ants (Barroso et al., 2013; Bottcher \& Oliveira, 2014; Farnese et al., 2011; Pizo \& Oliveira, 1998; 2000).

Ants interact with diaspores by taking them to their nest or cleaning them, which causes carrying by the removal of aril or pulp. Diaspore removal allows seedlings to establish themselves away from the mother-plant, which reduces intraspecific competition and helps them escape predators and pathogens (Howe \& Smallwood, 1982). Moreover, diaspore cleaning prevents pathogen attacks and facilitates seed germination (Christianini et al., 2012; Lima et al., 2013; Santana et al., 2013).
Studies show that the selection of non-myrmecochorous diaspore by ants depends on some characteristics, such as diaspore size, abundance, and the presence of fleshy tissues (Crist \& MacMahon, 1992; Christianini et al., 2012; Farnese et al., 2011; Pizo \& Oliveira, 2000; Willot et al., 2000). Size and presence of fleshy tissues are the characteristics that better explain ant attraction (Christianini et al., 2012; Farnese et al., 2011; Willot et al., 2000) while abundance seems to have a minor importance, and generally explains less than $30 \%$ of some ant species' preference variation (Cris \& MacMahon, 1992; Willot et al., 2000).

Although abundance is referred to as the least important characteristic, the frequency of seed collection by ants depends mainly on the abundance of their preferred food (Cris \& MacMahon, 1992; Pizo \& Oliveira, 2000; Pol et al., 2011; Willot et al., 2000). Hence, ants respond to seasonal variations in resource availability (Cris \& MacMahon, 1992; Pol et al., 2011). One species fruiting period with suitable food resource allows ants to be more selective and concentrate their activity in areas with higher availability of that plant, which narrows

\footnotetext{
${ }^{1}$ Universidade Federal Rural do Rio de Janeiro (UFRRJ), Seropédica, RJ, Brasil

${ }^{2}$ Universidade Estadual Paulista Júlio de Mesquita Filho (Unesp), Rio Claro, SP, Brasil
} 
their diet, and consequently, leads to a higher number of interactions with the diaspore (Wilby \& Shachak, 2000).

We assessed the importance of diaspore abundance in interaction with ants and tested whether the number of interactions during the day relates to variations in seed availability. We expected an increased number of interactions when diaspore availability was high. We also evaluated whether the ants changed their foraging behavior because of the higher diaspores abundance. Thus, we tested whether the number of ants was higher at stations with a higher number of diaspores, and if the mean number of ants per seed was also higher in the same seasons. We expected the number of ants and mean number of ants per seed to be directly proportional with diaspores abundance at stations.

\section{MATERIALS AND METHODS}

\subsection{Study site}

This study was carried out in a second-growth forest at Marambaia Island, Rio de Janeiro State, southeastern Brazil $\left(23^{\circ} 2^{\prime} \mathrm{S}, 43^{\circ} 35^{\prime} \mathrm{W}\right)$. The island is located within the Tropical Atlantic Morphoclimatic Domain, with average monthly temperatures above $20^{\circ} \mathrm{C}$. March is the warmest month, with an average maximum temperature of $30^{\circ} \mathrm{C}$ (Mattos, 2005). Rainfall is high, with an average annual rainfall above $1,000 \mathrm{~mm}$, and abundant rains occur mainly from November to March (average rainfall above $100 \mathrm{~mm}$ ) (Mattos, 2005). The island has different vegetation types such as mangroves, resting (i.e., coastal vegetation) and hillside Atlantic Forest (Conde et al., 2005), where this study was conducted.

\subsection{Plant species studied}

We used diaspores of the non-myrmecochorous species Guarea guidonia (L.) Sleumer (Meliaceae) as a resource to assess the importance of diaspore abundance in interactions with ants. To avoid influence of diaspore size and presence of fleshy tissues, we used a single species, the tree G. guidonia, extremely common in the Atlantic Forest of southeastern Brazil. Its fruits are dry dehiscent capsules, with seeds covered by a red sarcotesta. The seeds are its dispersal unit and vary from 10 to $12 \mathrm{~mm}$. The fruits open from December to April in the island and are an important resource for ants in that period. The seeds can be found after the fruits dehiscence grouped or isolated.

\subsection{Sampling methods}

We set up 40 sampling stations at 10-m intervals along a 400-m long trail in March 2015, the peak of G. guidonia fruiting period. We used 10-m intervals to maintain the different ant colonies independence. Stations consisted of $8 \times 8 \mathrm{~cm}$ filter paper pieces to facilitate observations in the litter. Each station had only one treatment, established randomly: 10 stations were provided with only one seed, 10 stations with two, 10 stations with five and 10 stations with ten seeds of G. guidonia. The objective of this difference was to assess whether seed abundance affects the number of interactions with ants. We established the stations at $12 \mathrm{p} . \mathrm{m}$. and observed them nine times in a 24 hour period (2 p.m., 4 p.m., 6 p.m., 8 p.m., 0 a.m., 6 a.m., 8 a.m., 10 a.m., 12 p.m.). Since there were ants active at different times of the day (diurnal, twilight and nocturnal), the 24-hour period allowed everyone access to interact with seeds. During observations, we counted the number of interactions (number of stations) and the number of foragers ants interacting at stations. We collected ants after the last observation to avoid interference in recruiting.

\subsection{Data analysis}

To test whether the number of interactions was higher at stations with higher abundance; and whether the number of foragers ants per seed was higher at stations with higher abundance, we used Kruskal-Wallis test (nonparametric data). The mean number of foragers ants per seed was calculated considering all stations (with or without ants). After, we used Dunn's test to multiple pairwise comparisons. To test the relationship between number of foragers ants and abundance stations, we used one-way ANOVA. We considered seed abundance as explaining variable and the mean number of foragers ants in the stations at each time as response variable. The mean number of foragers ants was calculated only to stations where we saw ants interacting with seeds on each observation, as to avoid influence of the number of interactions. Data were $\log$ transformed to meet the assumptions of homogeneity of variances. We used Tukey's test to compare means.

After 24 hours, we counted the number of removals and estimated the percentage of seed cleaning. We estimated the cleaning of each seed not removed at $0 \%$ (no cleaning), 25\% (until $1 / 4$ ), 50\% (between $1 / 4$ and $1 / 2$ ), $75 \%$ (between $1 / 2$ and $3 / 4$ ) and $100 \%$ (over $3 / 4$ ). We calculated the average percentage of seeds cleaned at each station according to the quantity of seeds available at the last observation. We used $\chi^{2}$-test to determine if there were differences at cleaning among the abundance treatments. As we worked with abundance, the data were not standardized. We had a total of 100 seeds in the 10 -seeds stations for a total of only 10 seeds in 1 -seed stations. To avoid differences because of abundance variation, we extrapolated the results with all the values proportional to 100 seeds (Melo \& Hepp, 2008). To test if a longer time of exploitation by ants led to more cleaning, we used Spearman correlation. 
We used the number of observations with interactions at each station throughout the day as explaining variable and average percentage of seeds cleaned at each station as response variable. Results were considered significant when $p<0.05$.

\section{RESULTS AND DISCUSSION}

We collected 11 ant species interacting with G. guidonia seeds after the last observation. Among them, one species interacted at stations with only one seed, four species at stations with two seeds and six species at stations with five and 10 seeds (Table 1). The number of interactions was significantly higher at stations with 10 seeds $(\mathrm{H}=19.73 ; \mathrm{df}=3 ; p<0.001$; Figure 1). In general, the number of interactions at stations with 10 seeds remained high throughout the day (Figure 2). Figure 2 shows the ants activity during the observation periods for each class of seed abundance. The number of ants was significantly higher at stations with 10 seeds (ANOVA $_{(3,32)}$ $\mathrm{F}=12.59 ; p<0.001$; Figure 3a). However, the mean number of ants per seed was similar among abundance treatments $(\mathrm{H}=5.43 ; \mathrm{df}=3 ; p=0.14$; Figure $3 \mathrm{~b})$.

There were only three, four, two and three removals at stations with one, two, five and 10 seeds, respectively. The medians of seeds cleaned were $25 \%, 13 \%, 17 \%$ and $24 \%$ at stations with one, two, five and 10 seeds, respectively. There were differences at cleaning among abundance treatments $\left(\chi^{2}=45.82 ; \mathrm{df}=12\right.$; $\mathrm{N}=165 ; p<0.001$; Figure 4). There was a positive correlation between the number of observations and the average percentage of seeds cleaned $\left(r_{\mathrm{s}}=0.59 ; \mathrm{df}=35 ; p<0.001\right.$; Figure 5$)$.

Table 1. Ant species recorded in the interaction experiment with Guarea guidonia seeds on Marambaia Island, RJ, Brazil. The table shows ant species present at stations with one, two, five or 10 diaspores.

\begin{tabular}{|c|c|c|c|c|}
\hline Ant species & $\begin{array}{c}1 \\
\text { seed }\end{array}$ & $\begin{array}{c}2 \\
\text { seeds }\end{array}$ & $\begin{array}{c}5 \\
\text { seeds }\end{array}$ & $\begin{array}{c}10 \\
\text { seeds }\end{array}$ \\
\hline Carebara brevipilosa Fernandez, 2004 & & & $\mathrm{x}$ & \\
\hline Crematogaster sp 1 & & & $\mathrm{x}$ & \\
\hline Ectatomma permagnum Forel, 1908 & & & $\mathrm{x}$ & $\mathrm{x}$ \\
\hline Pheidole lucaris Wilson, 2003 & & $\mathrm{x}$ & & \\
\hline Pheidole radoszkowskii Mayr, 1883 & & $\mathrm{x}$ & $\mathrm{x}$ & $\mathrm{x}$ \\
\hline $\begin{array}{l}\text { Pheidole transversostriata } \\
\text { Mayr, } 1887\end{array}$ & & $\mathrm{x}$ & & \\
\hline Pheidole sp10 & & & & $\mathrm{x}$ \\
\hline Solenopsis bicolor (Emery, 1905) & & & $\mathrm{x}$ & $\mathrm{x}$ \\
\hline Solenopsis orestes Forel, 1903 & & & & $\mathrm{x}$ \\
\hline $\begin{array}{l}\text { Wasmannia auropunctata } \\
\text { (Roger, 1863) }\end{array}$ & $\mathrm{x}$ & $\mathrm{x}$ & & $\mathrm{x}$ \\
\hline Wasmannia lutzi Forel, 1908 & & & $\mathrm{x}$ & \\
\hline
\end{tabular}

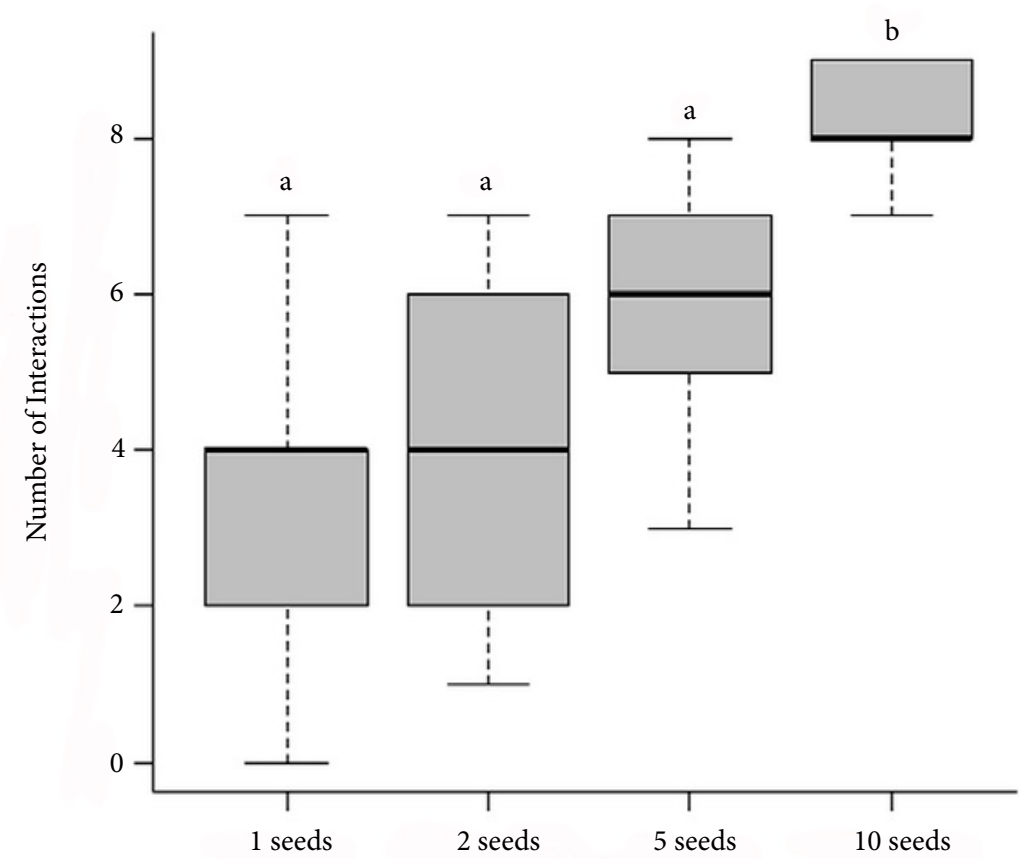

Figure 1. Number of interactions with ants for stations with one, two, five and 10 diaspores, after 24 hours of observation. Different letters represent statistical difference between stations $(p<0.05)$. 


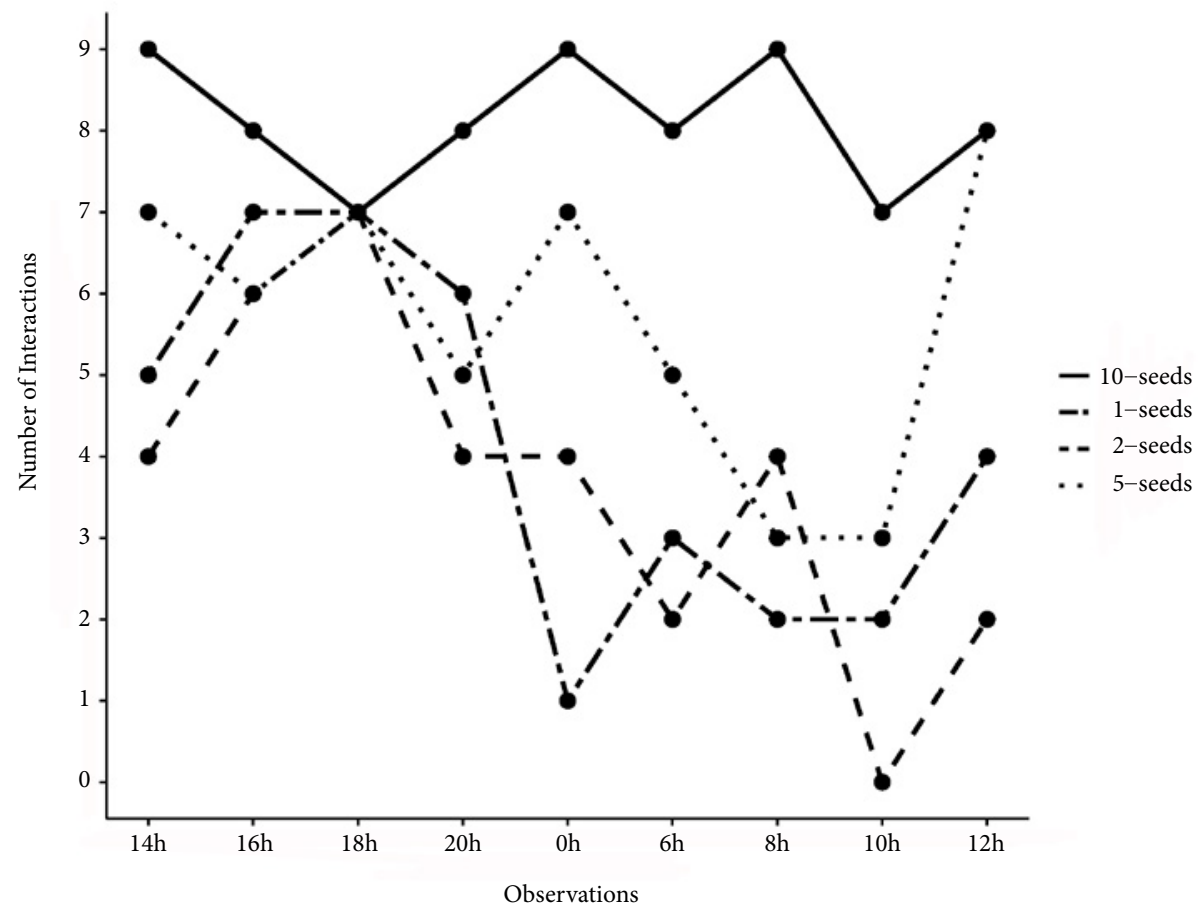

Figure 2. Variation in the number of interactions between ants and Guarea guidonia diaspores throughout nine observations in a 24 hours period, at stations with one, two, five and 10 diaspores.

(a)

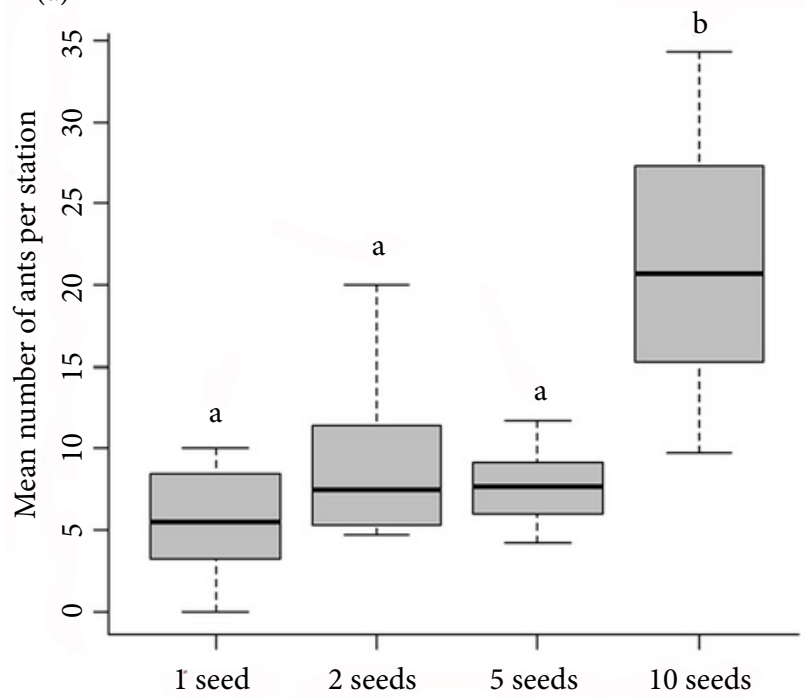

(b)

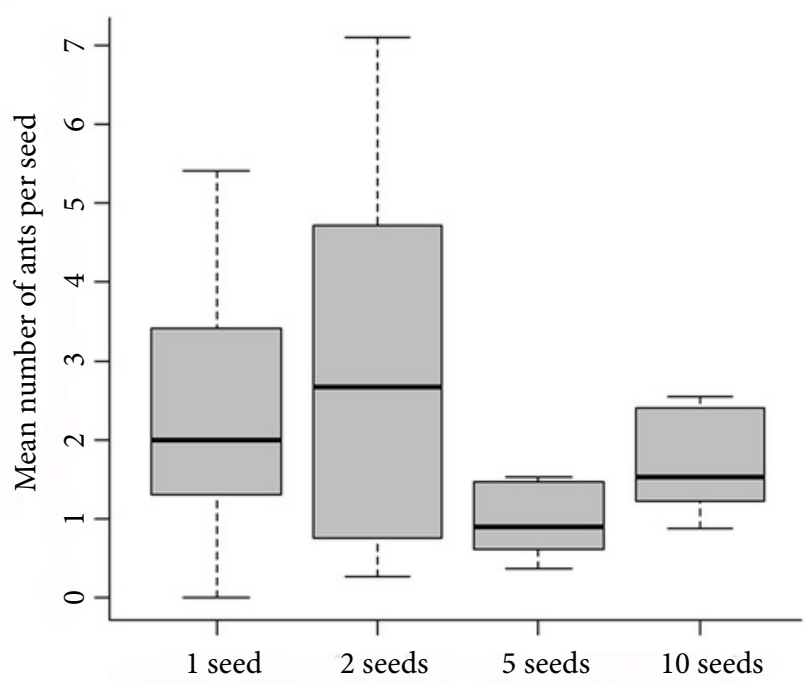

Figure 3. (a) Mean number of ants for stations with one, two, five and 10 diaspores and (b) mean number of ants per seed in stations with one, two, five and 10 diaspores. Different letters represent statistical difference between stations $(p<0.05)$. 


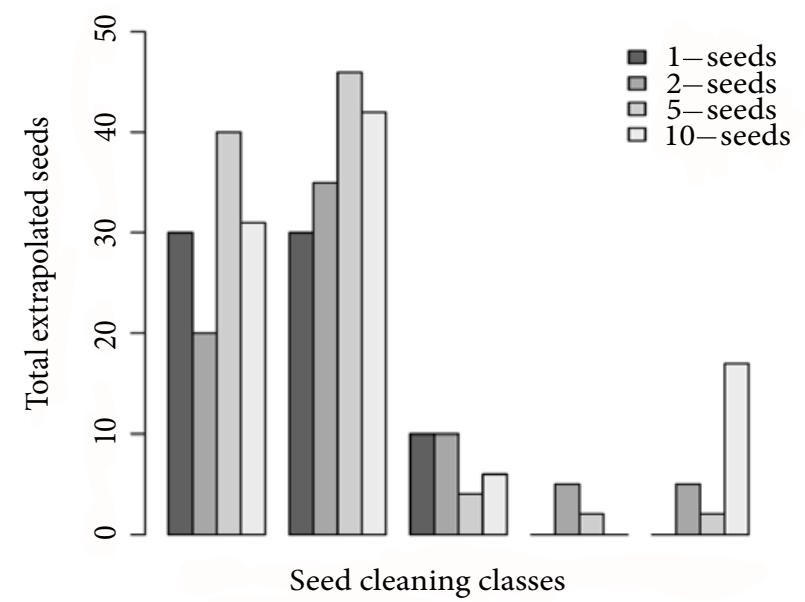

Figure 4. Total cleaned seeds grouped in different seeds cleaning classes for each abundance station (one, two, five and 10 seeds). Total number of seeds of each abundance represents the proportion of seeds for a total of 100 seeds.

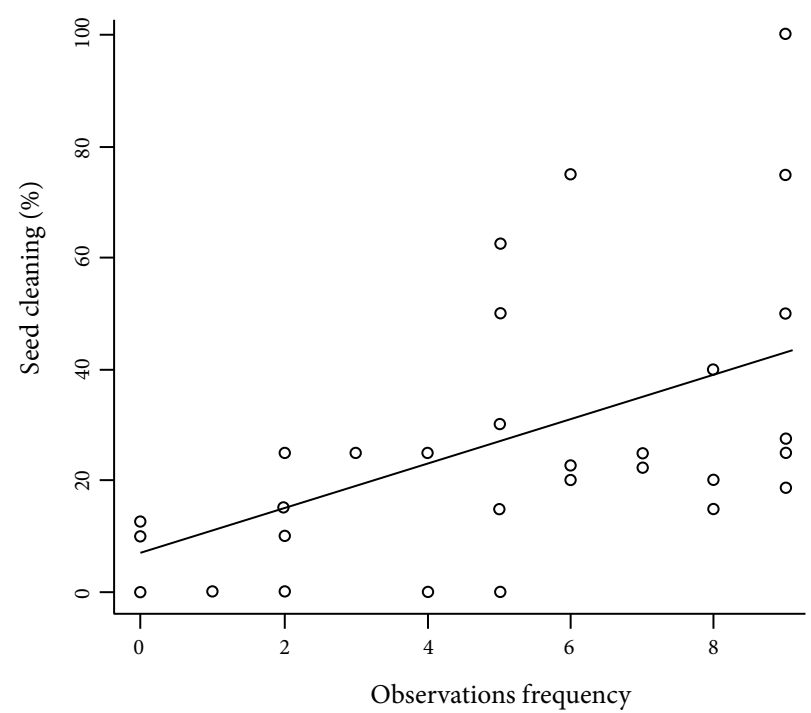

Figure 5. Relationship between the quantity of observations with ant-seed interactions and seed cleaning percentage $(p<0.001)$.

Our results suggest that increased fruit production by a plant species results in a greater number of diaspores available in the environment and these tend to be used more intensively by ant species than when seeds abundance and availability are low (Pol et al., 2011; Willot et al., 2000). This occurs mainly when diaspores are attractive to ants (Cris \& MacMahon, 1992; Pizo \& Oliveira, 2000; Willot et al., 2000). Thus, G. guidonia seeds may constitute a very attractive resource for ants. In our study, the high abundance of G. guidonia seeds allowed for a greater number of interactions with ants throughout the observation period. In low abundance, the seeds were not attractive enough to keep ant activity, which only explored the seeds for a short time.

Stations with 10 seeds were occupied by the most common ant species, which remained at the stations along the observation time. This persistence suggests that G. guidonia is a good reward and its abundance establishes an energy source that probably compensates foraging costs (Flanagan et al., 2012; Pol et al., 2011; Radtke, 2011). Analyzing ants of the genus Pogonomyrmex, Flanagan et al. (2012) found that aggregated seeds distributions are collected faster than isolated seeds, probably because of decreased search time. The time ants take to discover seeds may even be longer in clustered seeds, but once found, there is no more time lost searching for a new source (Denny et al., 2001; Flanagan et al., 2012). Here, we consider aggregation and abundance as the same thing, since the foragers' radius of detection varies from millimeters to a few centimeters (Pearce-Duvet \& Feener, 2010).

Stations with one, two and five seeds had some individuals, but there was no recruitment, or it occurred fewer times. At 10-seed stations, however, the ants recruited and kept their activity throughout the experiment (from the discovery time to the end of the experiment). This indicates that the ants discovered different stations equally, but only kept activity at the ones that compensated energy. This result agrees with Pearce-Duvet \& Feener (2010), who found that ants' discovery ability has no impact on the type or size of resources. For the authors, ants do not find larger or more concentrated resources quickly and this may be because (1) type of resource matters more than quantity or (2) ants only distinguish resource types roughly, but do not distinguish differences in quantity (Pearce-Duvet \& Feener, 2010). Since this study analyzes only one type of resource (G. guidonia seeds), only the second option is appliable here.

Stations with 10 seeds had a greater number of ants, although this pattern was not maintained when considered the mean per seeds, i.e., the mean number of workers per seed is equal, regardless of seed abundance. This result may reflect the species' foraging behavior. Colonies of different sizes allocate similar proportions of foragers to seed clusters (Flanagan et al., 2012). Moreover, the greater number of ants per station is a simple result of a greater amount of resource supporting a larger population (MacArthur \& MacArthur, 1961; Pigot et al., 2016).

Most of the ants that interacted with the seeds belong to the genera Pheidole, Solenopsis and Wasmannia, who generally have dominant and recruiting omnivorous species (Baccaro et al., 2015). The recruitment promotes greater seed cleaning, since the number of ants removing sarcotesta is increased. Species of Pheidole are important for seeds dispersal (Baccaro et al., 2015), although some species are considered 
granivorous (Pirk et al., 2009). However, Pheidole species only carry seeds that offer a high energy return (Pirk et al., 2009). As for G. guidonia, the sarcotesta is an energetic resource, but removing it locally seems less expensive for the ants than carrying the entire seed to their nest. We also observed the presence of poneromorph ants (E. permagnum), which are high quality dispersers (Leal et al., 2014).

The removal of G. guidonia seeds in the island is performed by poneromorph ants (personal observation), but were infrequent at the stations probably because of an occupation by dominant recruiter ant species. About seed cleaning, stations with 10 seeds supported higher number of interactions and foragers ants resulting in higher cleaning rates. Our analysis also showed that seed cleaning was higher at stations with more observations along the day. That is, stations with low abundance explored by ants throughout the day also benefited from seed cleaning. Ant cleaning is advantageous for plants considering it prevents pathogen attacks and promotes seed germination, as recorded in other plant species (Christianini et al., 2012; Lima et al., 2013, Santana et al., 2013) and G. guidonia (Silva et al., 2019).

\section{CONCLUSIONS}

In summary, beyond the importance of the resources offered by diaspores (such as pulp or aril), diaspore abundance is also an important factor to facilitate ant-plant interactions. Higher abundance of diaspores leads to higher seed cleaning, which is important for promoting increased germination, thus favoring plant development. Thereby, high abundance of diaspores can be considered an evolutionary advantage for plants obtained by interaction with ants.

\section{ACKNOWLEDGEMENTS}

The authors thank Assessment Center of Ilha da Marambaia (CADIM) for logistical support during research. The study is part of the master's project of the first author. We also thank the editor and anonymous reviewers for their insightful comments and suggestions, which helped improve the manuscript.

\section{SUBMISSION STATUS}

Received: 23 May 2018

Accepted: 24 Nov. 2018

Associate editor: Rodrigo Studart Corrêa

(D) 0000-0002-9422-2629

\section{CORRESPONDENCE TO}

\section{Bianca Ferreira Silva}

Universidade Federal Rural do Rio de Janeiro (UFRRJ), Rodovia BR-465, km 7, s/n, CEP 23890-000, Seropédica, RJ, Brasil e-mail: bianca.fsilva@hotmail.com

\section{FINANCIAL SUPPORT}

Coordenação de Aperfeiçoamento de Pessoal de Nível Superior (Capes) - Finance Code 001.

\section{REFERENCES}

Baccaro FB, Feitosa RM, Fernández F, Fernandes IO, Izzo TJ, Souza JLP, Solar RRC. Guia para os gêneros de formigas do Brasil. 1st ed. Manaus: INPA; 2015.

Barroso A, Amor F, Cerdá X, Boulay RR. Dispersal of nonmyrmecochorous plants by a "keystone disperser" ant in a Mediterranean habitat reveals asymmetric interdependence. Insectes Sociaux 2013; 60(1): 75-86. 10.1007/s00040-012-0268-0

Bottcher C, Oliveira PS. Consumption of lipid-rich seed arils improves larval development in a Neotropical primarily carnivorous ant Odontomachus chelifer (Ponerinae). Journal of Tropical Ecology 2014; 30(6): 621-624. 10.1017/S0266467414000479

Christianini AV, Mayhé-Nunes AJ, Oliveira PS. Exploitation of fallen diaspores by ants: are there ant-plant partner choices? Biotropica 2012; 44(3): 360-367. 10.2307/41496007

Conde MMS, Lima HRP, Peixoto AL. Aspectos florísticos e vegetacionais da Marambaia, Rio de Janeiro, Brasil. In: Menezes LFT, Peixoto AL, Araújo DSD, editors. História natural da Marambaia. Seropédica: EDUR; 2005. p. 133-168.

Crist TO, MacMahon JA. Harvester ant foraging and shrub-steppe seeds: interactions of seeds resources and seed use. Ecology 1992; 73(5): 1768-1779. 10.2307/1940028

Denny AJ, Wright J, Grief B. Foraging efficiency in the wood ant, Formica rufa: is time of the essence in trail following? Animal Behaviour 2001; 62(1): 139-146. 10.1006/anbe.2001.1718

Farnese FS, Campos RB, Fonseca GA. Dispersão de diásporos não mirmecocóricos por formigas: influência do tipo e abundância do diásporo. Revista Árvore 2011; 35(1): 125-130. 10.1590/S010067622011000100015

Flanagan TP, Letendre K, Burnside WR, Fricke GM, Moses ME. Quantifying the effect of colony size and food distribution on harvester ant foraging. PLoS One 2012; 7(7): e39427. 10.1371/ journal.pone.0039427

Howe HF, Smallwood J. Ecology of seed dispersal. Annual Review of Ecology and Systematics 1982; 13: 221-228. 10.1146/annurev. es.13.110182.001221

Leal LC, Lima Neto MC, Oliveira AFM, Andersen AN, Leal IR. Myrmecochores can target high-quality disperser ants: variation in elaiosome traits and ant preferences for myrmecochorous Euphorbiaceae in Brazilian Caatinga. Oecologia 2014; 174(2): 493500. $10.1007 / \mathrm{s} 00442-013-2789-2$

Lengyel S, Gove AD, Latimer AM, Majer JD, Dunn RR. Convergent evolution of seed dispersal by ants, and phylogeny and biogeography in flowering plants: a global survey. Perspectives in Plant Ecology, Evolution and Systematics 2010; 12(1): 43-55. 10.1016/j. ppees.2009.08.001

Lima HC, Oliveira EG, Silveira FAO. Interactions between ants and nonmyrmecochorous fruits in Miconia (Melastomataceae) 
in a Neotropical Savanna. Biotropica 2013; 45(2): 217-223. 10.1111/j.1744-7429.2012.00910.x

MacArthur RH, MacArthur JW. On bird species diversity. Ecology 1961; 42(3): 594-598. 10.2307/1932254

Mattos CLV. Caracterização climática da Restinga da Marambaia. In: Menezes LFT, Peixoto AL, Araújo DSD, editors. História natural da Marambaia. Seropédica: EDUR; 2005. p. 55-66.

Melo AS, Hepp LU. Ferramentas estatísticas para análises de dados provenientes de biomonitoramento. Oecologia Brasiliensis 2008; 12(3): 463-486.

Pearce-Duvet JMC, Feener DH Jr. Resource discovery in ant communities: do food type and quantity matter? Ecological Entomology 2010; 35(5): 549-556. 10.1111/j.1365-2311.2010.01214.x

Pigot AL, Tobias JA, Jetz W. Energetic constraints on species coexistence in birds. PLoS Biology 2016; 14(3): e1002407. 10.1371/ journal.pbio.1002407

Pirk GI, Pasquo F, Casenave JL. Diet of two sympatric Pheidole spp. ants in the central Monte desert: implications for seed-granivore interactions. Insectes Sociaux 2009; 56(3): 277-283. 10.1007/s00040009-0021-5

Pizo MA, Oliveira PS. Interactions between ants and seeds of a nonmyrmecochorous neotropical tree, Cabralea canjerana (Meliaceae), in the Atlantic forest of southeast Brazil. American Journal of Botany 1998; 85(5): 669-674. 10.2307/2446536
Pizo MA, Oliveira PS. The use of fruits and seeds by ants in the Atlantic forest of southeast Brazil. Biotropica 2000; 32(4b): 851-861. 10.1111/j.1744-7429.2000.tb00623.x

Pol RG, Casenave JL, Pirk GI. Influence of temporal fluctuations in seed abundance on the foraging behaviour of harvester ants (Pogonomyrmex spp.) in the central Monte desert, Argentina. Austral Ecology 2011; 36(3): 320-328. 10.1111/j.1442-9993.2010.02153.x

Radtke TM. Granivore seed-size preferences. Seed Science Research 2011; 21(2): 81-83. 10.1017/S0960258511000031

Santana FD, Cazetta E, Delabie JHC. Interactions between ants and non-myrmecochorous diaspores in a tropical wet forest in southern Bahia, Brazil. Journal of Tropical Ecology 2013; 29(1): 71-80. 10.1017/S0266467412000715

Silva BF, Azevedo IHF, Mayhé-Nunes A, Breier TB, Nunes-Freitas AF. Ants promote germination of the tree Guarea guidonia by cleaning its seeds. Floresta e Ambiente 2019; 26(3): e20180151. $10.1590 / 2179-8087.015118$

Wilby A, Shachak M. Harvester ant response to spatial and temporal heterogeneity in seed availability: pattern in the process of granivory. Oecologia 2000; 125(4): 495-503. 10.1007/s004420000478

Willot SJ, Compton SG, Incoll LD. Foraging, food selection and worker size in the seed harvesting ant Messor bouvieri. Oecologia 2000; 125(1): 35-44. 10.1007/PL00008889 